\title{
Multifocal invasive ductal breast cancer with osteoclast-like giant cells: a case report
}

\author{
Georg Richter $^{1 *}$, Christoph Uleer ${ }^{2}$, Thomas Noesselt ${ }^{3}$
}

\begin{abstract}
Introduction: To the best of our knowledge, this is the first case report of a multifocal (trifocal) invasive carcinoma of the breast containing osteoclast-like giant cells.

Case presentation: A 64-year-old Caucasian woman presented for routine mammography screening with three radiodense lesions in the lower inner quadrant of the right breast, a primary breast cancer. Microscopic examination showed three foci of invasive ductal carcinoma with multinucleated osteoclast-like giant cells. Osteoclast-like giant cells in breast cancer are a rare phenomenon. They are described in less than two percent of all breast cancers and occur in association with invasive ductal cancer and invasive lobular cancer. In addition, osteoclast-like giant cells have been described in several sarcomas and metaplastic carcinomas of the breast.

Conclusion: To the best of our knowledge, this is the first report of a multifocal infiltrating ductal carcinoma of the breast containing osteoclast-like giant cells. This could be an indication for a possible early event in carcinogenesis associated with a biological event or secretion that indicates the differentiation and/or migration of stromal cells or macrophages.
\end{abstract}

\section{Introduction}

Carcinoma of the breast containing osteoclast-like giant cells is uncommon and described in less than $2 \%$ of breast cancer patients [1-3]. In addition, osteoclast-like giant cells are described in a ductal carcinoma in situ and metaplastic carcinomas of the breast $[4,5]$, although the stromal origin of the giant cells is unknown. Immunohistochemical and ultrastructural studies suggest that the osteoclast-like giant cells are of stromal histiocytic origin or might be differentiated from macrophages [6-9]. The characteristic multinucleated giant cells are found at the periphery of the tumor cells and within the glandular luminal spaces in primary in situ, invasive breast cancers and in metastases. We report the first case of a multifocal invasive ductal breast cancer with osteoclast-like giant cells.

\section{Case presentation}

A 64-year-old Caucasian woman presented for routine mammography screening within the National Mammography Screening Program. She had no known family

\footnotetext{
* Correspondence: richter@pathologie-hannover.de

'Institute of Pathology, 31785, Hameln, Germany

Full list of author information is available at the end of the article
}

history of breast cancer and denied recent signs or symptoms of breast disease on her intake questionnaire.

The digital mammogram showed three radiopaque lesions in the lower inner quadrant of the right breast, which were readily detectable in both the mediolateral oblique and craniocaudal projection views (Figure 1). The density of the breast tissue was estimated as type 2 according to the classification system of the American College of Radiology (low-density, fibroglandular tissue). Round microcalcifications were found to be diffusely distributed in both breasts.

Each of the three lesions in the right lower inner quadrant had slightly irregular margins and measured $0.7 \mathrm{~cm} \times 0.9 \mathrm{~cm}$. Since these lesions were absent in the previous screening mammogram performed two years earlier (Figure 2), they were considered suspicious for multifocal breast cancer (Breast Imaging Reporting and Data System (BI-RADS) category 4B). Therefore, the woman was called back into the screening center for further evaluation. A craniocaudal spot compression view focused on the three lesions was obtained. On this view, the radiodense lesions with irregular margins were easily distinguished from the surrounding fat tissue (Figure 3). 


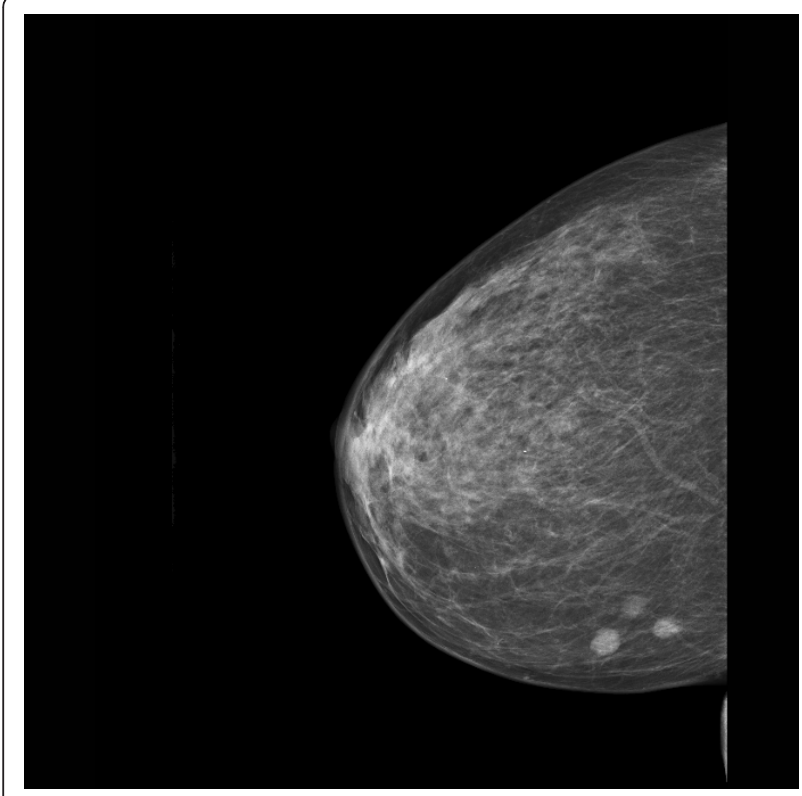

Figure 1 Digital mammography (mediolateral projection).

A breast ultrasound was performed, and in the right inner lower quadrant the lesions were visible as complex masses with irregular margins and inhomogeneous internal echoes (BI-RADS analogue 4). The left breast as well as the ipsilateral and contralateral axillary lymph nodes were normal.

Since there was a good correlation between the suspicious mammographic lesions and the ultrasound image,

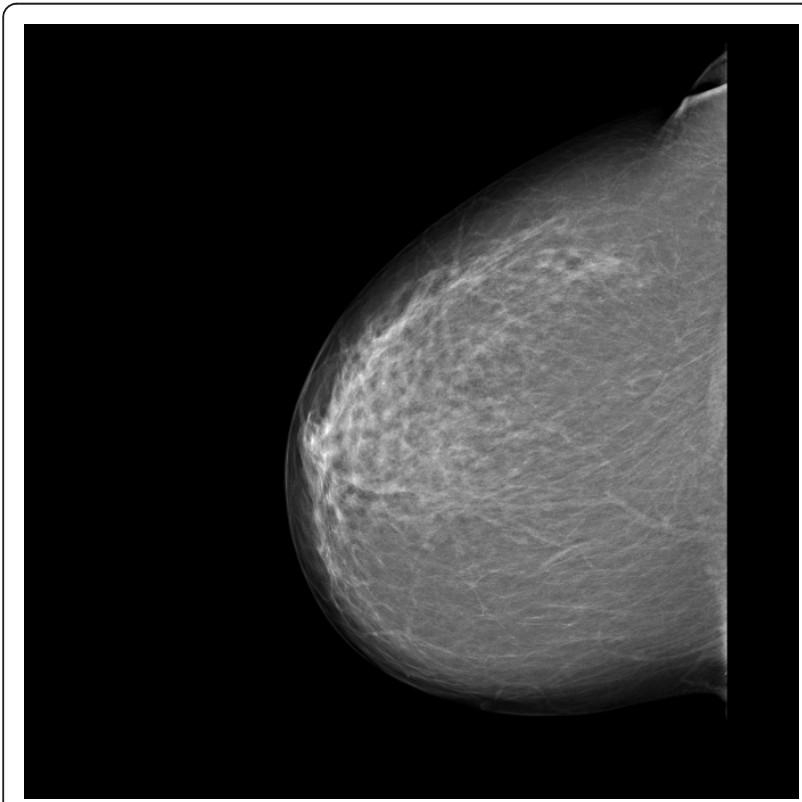

Figure 2 Screening mammogram performed two years earlier than 2009

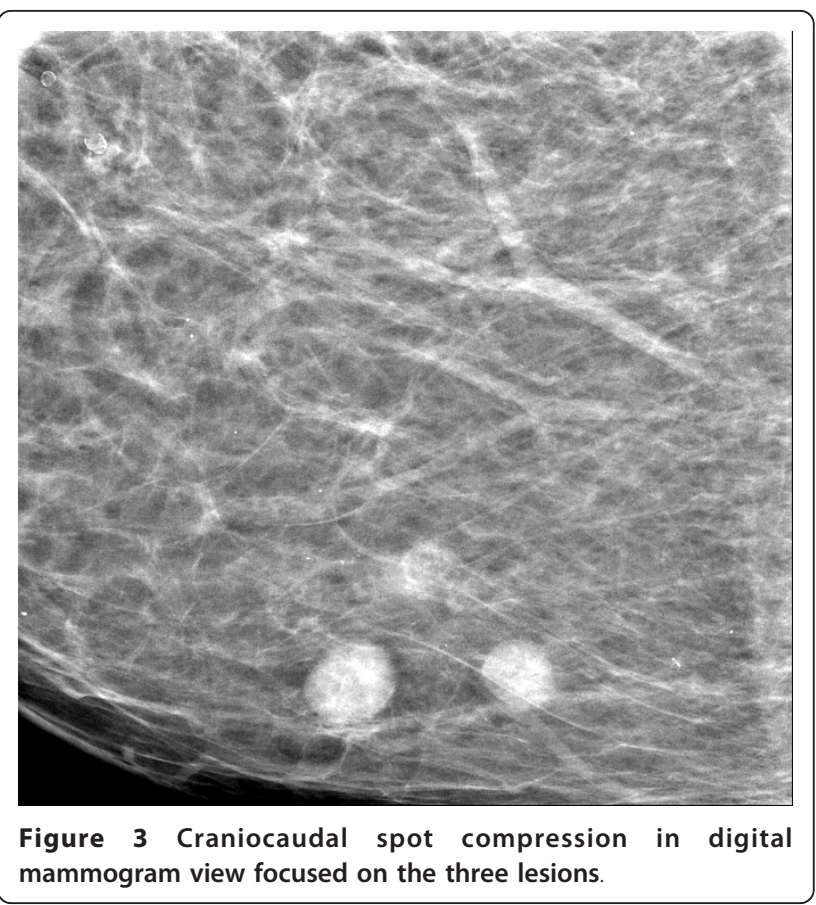

an ultrasound-guided core needle biopsy was performed for each of the three tumors. Five specimens were thereby obtained confirming the diagnosis of multifocal invasive cancer. Because of the multifocal character of the breast cancer, a bilateral breast magnetic resonance imaging (MRI) scan was obtained to exclude further lesions. Eleven days after the woman's first contact with the screening center, the interdisciplinary tumor board recommended breast-conserving surgery and sentinel node biopsy following preoperative needle localization of the tumor.

As the foci were lying close together in one quadrant, a breast-preserving operation could be performed. Additionally, a sentinel node marking and a sentinel node biopsy were induced by clinically and sonographically negative axillary results.

For the operation, the three foci were portrayed preoperatively using sonography with a needle marking. First, the sentinel node biopsy was carried out. After marking with Nanocoll technetium-99 m (Gipharma Sri, Saluggia Vercelli, Italy) a sentinel node was portrayed in the right axilla by lymphscintigraphy. Intraoperative 1.5 $\mathrm{ml}$ Acid Blue solution (Guerbet, Sulzbach, Taunus, Germany) was additionally injected peritumorally, and the axilla was examined using a gamma probe. A focus of heightened activity showed up in the right lower axilla. A radioactively marked lymph node was found during the preparation of the axilla. There were no other foci of heightened activity. The frozen section examination of the sentinel node was negative. 
Afterward a breast-preserving excision including a skin spindle was performed. The excision contained all the invasive foci and presented clear margins. For reconstruction, intramammary wound closure with an advancement plastic of breast tissue was installed into the defect. Postoperative proper wound healing was observed.

An intraoperative investigation of a breast specimen weighing $31 \mathrm{~g}$ and measuring $8 \mathrm{~cm} \times 5 \mathrm{~cm} \times 3 \mathrm{~cm}$ was undertaken to examine the resection margins. Also, one sentinel node was examined to exclude metastases. In the macroscopic examination, three neighboring foci showing a brown incision surface and measuring $1.2 \mathrm{~cm}, 0.8$ $\mathrm{cm}$ and $0.6 \mathrm{~cm}$ were found (Figure 4 ). The specimens were routinely fixated in $4 \%$ buffered formalin, embedded in paraffin and sectioned into $3 \mu \mathrm{m}$ to $4 \mu \mathrm{m}$ thick sections. Then the specimens were routinely stained with hematoxylin and eosin. Also, they were immunohistochemically stained with the primary antibodies Cytokeratin 5/6 (Cell Marque) (Roche Ventana Medical Systems, Illkirch, France), Cytokeratin 7 (Roche Ventana), Vimentin (Roche Ventana), CD68 (Roche Ventana), Estrogen Receptor (Roche Ventana), Progesterone Receptor (Roche Ventana), human epidermal growth factor receptor 2 (HER2) (Roche Ventana) and Ki-67 antigen (Roche Ventana) using the ultraView ${ }^{\mathrm{TM}}$ Universal Alkaline Phosphatase Red Detection Kit (Roche Ventana) on the Roche Ventana benchmark with on-slide positive controls. All Ventana kits are ready to use.

Microscopic examination showed three foci of an invasive ductal carcinoma with a moderate amount tubule formations, moderate nuclear pleomorphism with visible nucleoli and 8 mitoses/10 high-power fields following the grading of Elston and Ellis [12] (Figures 5 and 6). No squamous cells or other metaplasia were exhibited in any of the foci. On the basis of immunohistochemistry, we detected a positive reaction for cytokeratin 7 and a negative reaction for cytokeratin 5/6 and vimentin in the epithelial tumor cells (Figure 7). Using the Allred score,

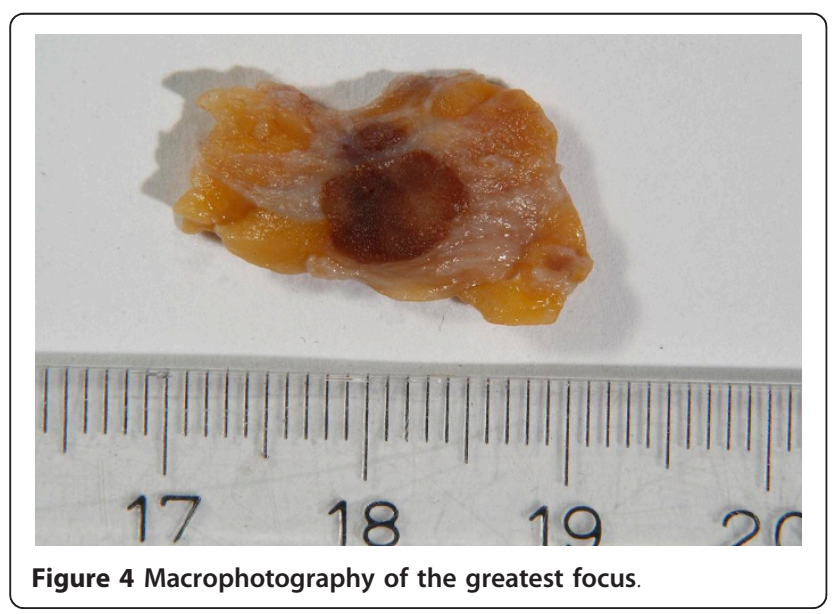

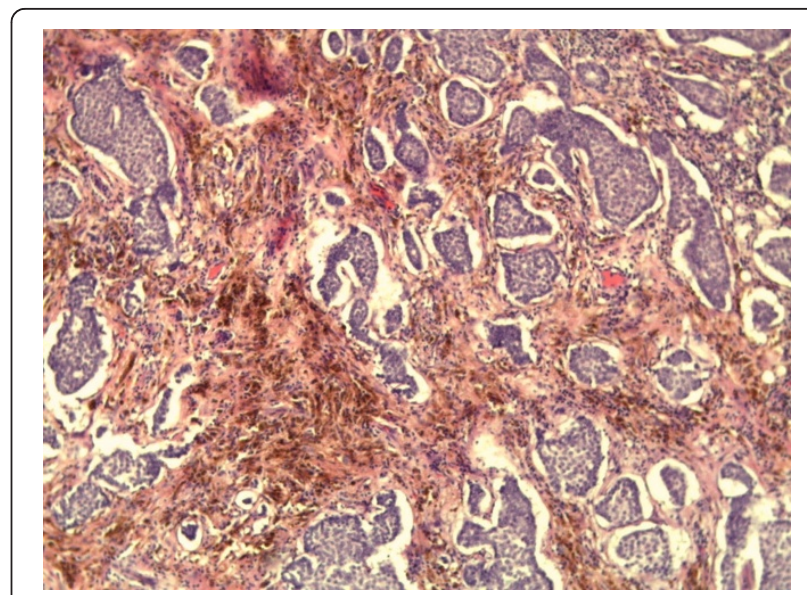

Figure 5 Microphotography (hematoxylin and eosin staining; original magnification, $\times 200$ ).

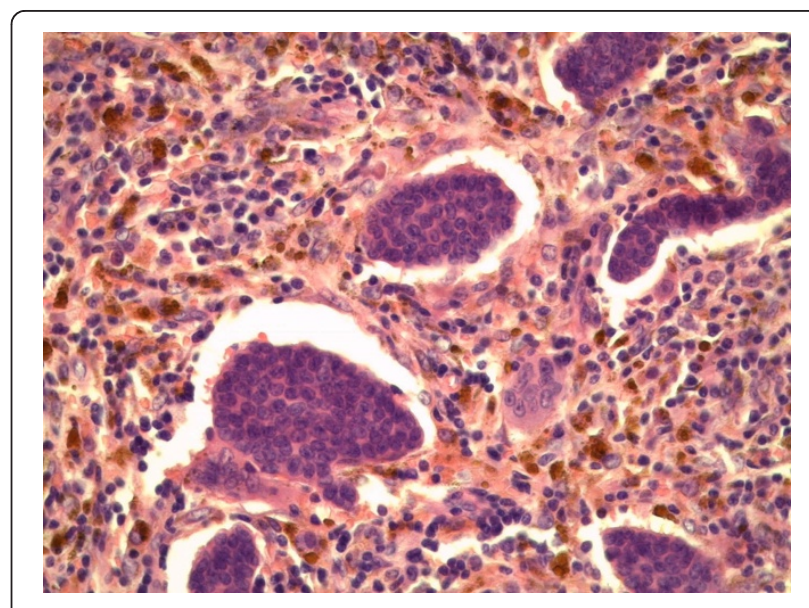

Figure 6 Microphotography (hematoxylin and eosin staining; original magnification, $\times 400$ )

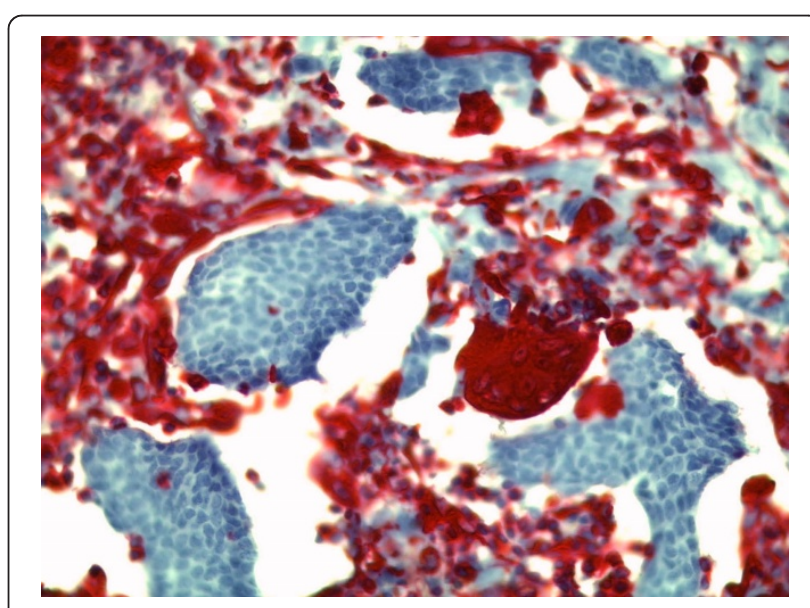

Figure 7 Immunohistochemical positive reaction of the stromal cells for vimentin (original magnification, $\times 400$ ) 
the estrogen and progesterone receptors were similarly positive in all three foci (Proportion Score $5+$ Intensity Score 3 = Total Score 8) (Figures 8 and 9), and in accordance with the Dako score, we detected a HER2 score of 0 (negative) (Figure 10). The Nottingham grade for invasive cancer was $0.2 \times 1.2+(\mathrm{G}) 2+0=3.4$; Nottingham Prognostic Index score 3.4 (intermediate). The giant cells contained numerous uniform nuclei and eosinophilic cytoplasm and had an appearance identical to an osteoclast. Immunohistochemically, the giant cells showed a positive reaction for vimentin and CD68 (Figure 11) and a negative reaction for the cytokeratins and the hormone receptors.

Owing to the tumor entity, there is a heightened risk of a systemic recurrence. Anthracycline-based chemotherapy with four cycles of epirubicin $90 \mathrm{mg} / \mathrm{m}^{2}$ and cyclophosphamide $600 \mathrm{mg} / \mathrm{m}^{2}$ was added as there was an overexpression of plasminogen activator inhibitor-1 (PAI-1, $54 \mathrm{ng} / \mathrm{mg}$; urokinase plasminogen activator, 1.1 $\mathrm{ng} / \mathrm{mg}$ ) as a prediction of the effectiveness for adjuvant chemotherapy. Our patient was treated with continuation of adjuvant therapy with aromatase inhibitor and radiation of the breast with 50.4 dye plus local boost radiotherapy of the tumor bed.

\section{Conclusion}

To the best of our knowledge, we present the first case report of a multifocal invasive ductal breast cancer with osteoclast-like giant cells. Osteoclast-like giant cells are rare in breast cancer, and the prognostic significance of their presence is uncertain $[10,11]$. Immunohistochemical and ultrastructural studies suggest that the osteoclast-like giant cells are of stromal histiocytic origin or possibly are terminally differentiated from macrophages. We detected three neighboring foci of an invasive ductal

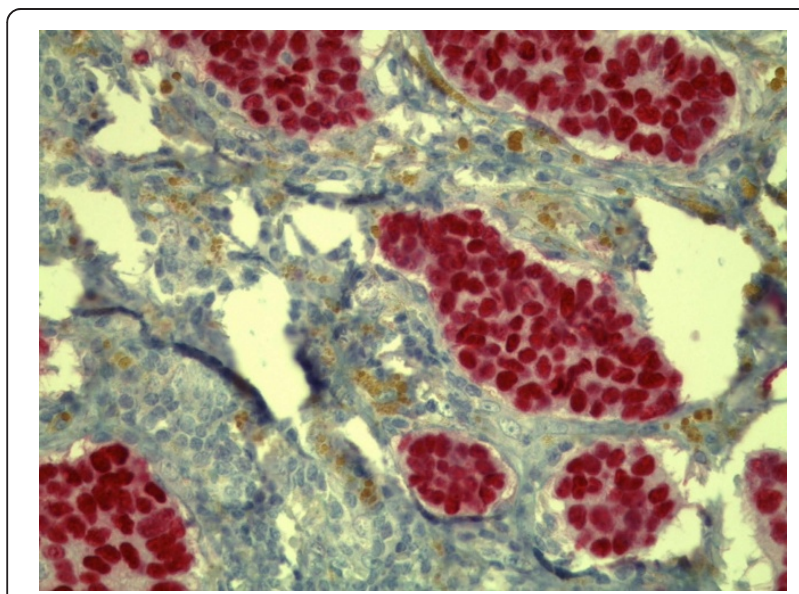

Figure 8 Immunohistochemical positive reaction with antibody against the estrogen receptor in the tumor cells (original magnification, $\times 400$ ).

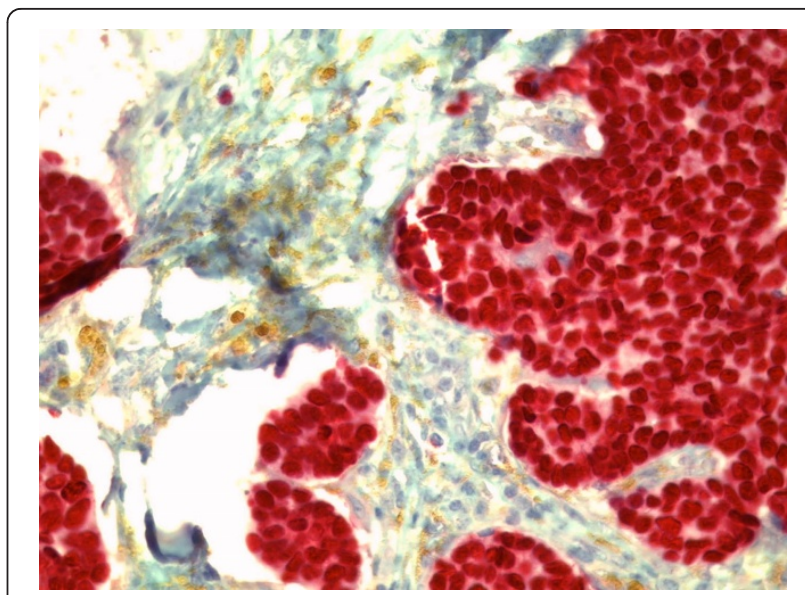

Figure 9 Immunohistochemical positive reaction with antibody against the progesterone receptor in the tumor cells (original magnification, $\times 400$ )

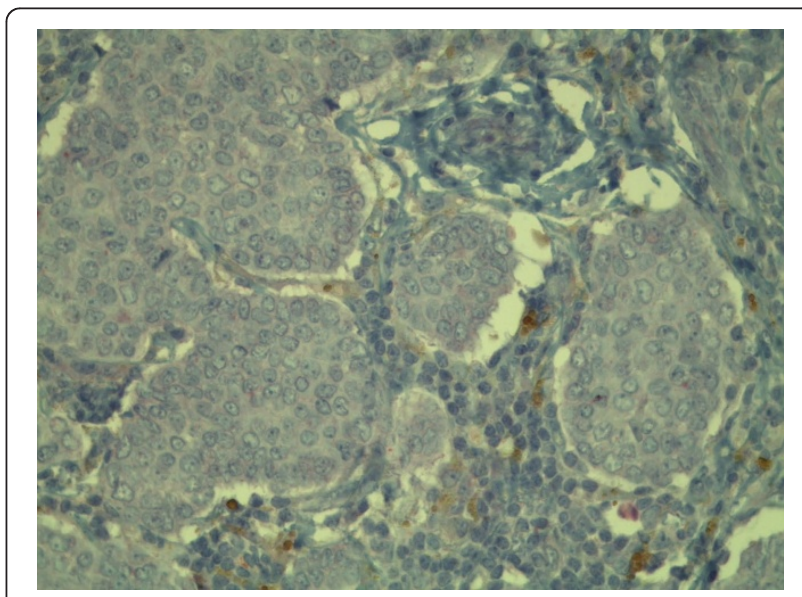

Figure $10 \mathrm{Imm}$ unohistochemical negative reaction with antibody against human epidermal growth factor receptor 2 (HER2)/neu in the tumor cells (original magnification, $\times 400$ ).

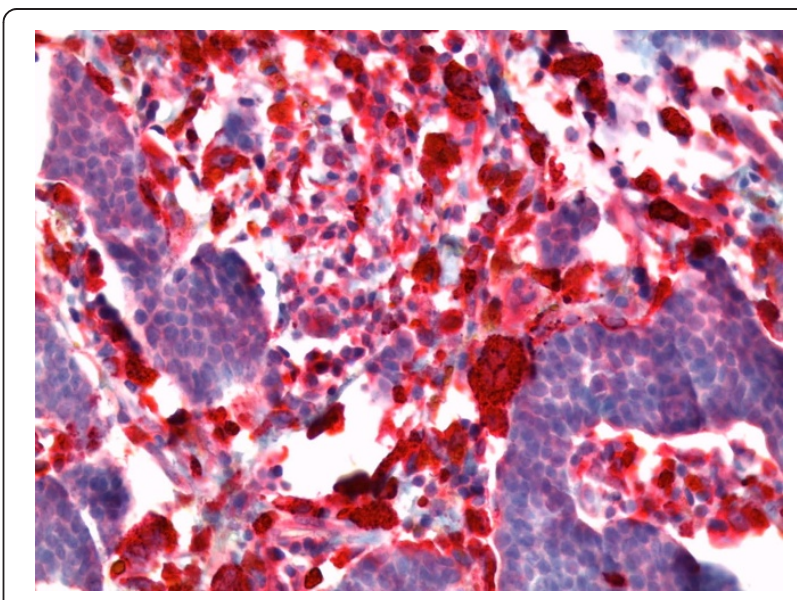

Figure 11 Immunohistochemical positive reaction with antibody against CD68 in the giant cells (original magnification, $\times 400$ ) 
breast cancer with giant cells containing numerous uniform nuclei and eosinophilic cytoplasm adjacent to the epithelial tumor cells, an appearance identical to osteoclasts. This could be an indication for a possible early event in carcinogenesis associated with a biological event or secretion that indicates the differentiation and/ or migration of stromal cells or macrophages.

\section{Consent}

Written informed consent was obtained from the patient for publication of this case report and accompanying images. A copy of the written consent is available for review by the Editor-in-Chief of this journal.

\section{Acknowledgements}

The authors thank the patient described in this study. Also, the authors would like to thank C. E. Noble-Pyott for her relentless and excellent work on this case report.

\section{Author details}

${ }^{1}$ Institute of Pathology, 31785, Hameln, Germany. ${ }^{2}$ Mammography Screening Unit Lower Saxony South, D-31134 Hildesheim-Hameln-Göttingen, Germany. ${ }^{3}$ Department of Gynecology, District Hospital Hameln, D-31785 Hameln, Germany.

\section{Authors' contributions}

UC analyzed and interpreted the mammography and ultrasound. TN performed the operation and administered chemotherapy. GR performed the histological examination and was a major contributor in writing the manuscript. All authors read and approved the final manuscript.

\section{Competing interests}

The authors declare that they have no competing interests.

Received: 17 May 2010 Accepted: 27 February 2011

Published: 27 February 2011

\section{References}

1. Rosen PP: Mammary carcinoma with osteoclast-like giant cells. Rosen's Breast Pathology Philadelphia: Lippincott Williams \& Wilkins; 2001, 517-526.

2. Holland $R$, van Haelst UJ: Mammary carcinoma with osteoclast-like giant cells: additional observations on six cases. Cancer 1984, 53:1963-1973.

3. Cai N, Koizumi J, Vazquez M: Mammary carcinoma with osteoclast-like giant cells: a study of four cases and a review of literature. Diagn Cytopathol 2005, 33:246-251.

4. Krishnan C, Longacre T: Ductal carcinoma in situ of the breast with osteoclast-like giant cells. Hum Pathol 2006, 37:369-372.

5. Wargotz ES, Norris HJ: Metaplastic carcinomas of the breast: V. Metaplastic carcinoma with osteoclastic giant cells. Hum Pathol 1990, 21:1142-1150.

6. Pettinato G, Petrella G, Manco A, di Pisco B, Salvatore G, Angrisani P. Carcinoma of the breast with osteoclast-like giant cells: fine needle aspiration cytology, histology and electron microscopy of 5 cases. Appl Pathol 1984, 2:168-178.

7. Sano M, Kikuchi K, Zhao C, Kobayashi M, Nakanishi Y, Nemoto N: Osteoclastogenesis in human breast carcinoma. Virchows Arch 2004 444:470-472.

8. Athanasou NA, Wells CA, Quinn J, Ferguson DP, Heryet A, McGee JO: The origin and nature of stromal osteoclast-like multinucleated giant cells in breast carcinoma: implications for tumour osteolysis and macrophage biology. Br J Cancer 1989, 59:491-498.

9. Shishido-Hara Y, Kurata A, Fujiwara M, Itoh H, Imoto S, Kamma H: Two cases of breast carcinoma with osteoclastic giant cells: are the osteoclastic giant cells pro-tumoural differentiation of macrophages? Diagn Pathol 2010, 5:55.
10. Agnantis NT, Rosen PP: Mammary carcinoma with osteoclast-like giant cells: a study of eight cases with follow up. Am J Clin Pathol 1979, 72:383-389.

11. Saimura M, Fukutomi T, Tsuda H, Tanaka SA, Nanasawa T: Breast carcinoma with osteoclast-like giant cells: a case report and review of the Japanese literature. Breast Cancer 1999, 6:121-126.

12. Elston CW, Ellis IO: Pathological prognostic, factors in breast cancer. 1. The value of histological grade in breast cancer: experience from a large study with long term follow up. Histopathology 1991, 19:403-410.

doi:10.1186/1752-1947-5-85

Cite this article as: Richter et al: Multifocal invasive ductal breast cancer with osteoclast-like giant cells: a case report. Journal of Medical Case Reports 2011 5:85.

\section{Submit your next manuscript to BioMed Central and take full advantage of:}

- Convenient online submission

- Thorough peer review

- No space constraints or color figure charges

- Immediate publication on acceptance

- Inclusion in PubMed, CAS, Scopus and Google Scholar

- Research which is freely available for redistribution 